\title{
CONGENITAL LOBAR EMPHYSEMA
}

\author{
BY \\ P. G. I. STOVIN \\ From the Bernhard Baron Institute of Pathology, The London Hospital
}

(RECEIVED FOR PUBLICATION MARCH 31, 1959)

The term congenital lobar emphysema was used by Robertson and James (1951) to denote infantile emphysema when pulmonary infection or intrabronchial foreign bodies are absent. Although in most instances only one lobe is affected, a few patients have emphysema of more than one lobe or subsequently develop emphysema of a second lobe (Kernan, 1944; Ehrenhaft and Taber, 1953 ; Sloan, 1953 ; Potts, Holinger and Rosenblum, 1954; Morse and Gladding, 1955 ; Holzel, Bennett, and Vaughan, 1956 ; Nelson, 1957 ; Contro, Miller, White, and Potts, 1958a and b; Sherman, 1959). However, as these multilobar cases are exceptional and as many authors have used the term congenital lobar emphysema, its adoption for this relatively specific clinical condition seems advisable.

Typical cases clinically exhibit either remittent or progressive dyspnoea and cyanosis, associated with severe unilateral emphysema and displacement of the mediastinum to the opposite side. Wheezing chest sounds are frequent and the temperature may be elevated. In several cases the condition of the infant is so critical that urgent surgical thoracic decompression by lobectomy is necessary. The symptoms often arise at or shortly after birth; their onset is rarely delayed beyond the sixth month.

In the present paper one case is described with a method of histological investigation which was found to be useful in elucidating its basic pathology.

\section{Case Report}

A premature male infant (birth weight $3 \mathrm{lb} .13 \mathrm{oz}$., 1,631 g.) developed normally despite three attacks in seven months of alleged pneumonia, the first of these occurring when he was 1 month old. When 8 months old he had a fourth attack and was admitted to the London Hospital with a pyrexia of $101^{\circ} \mathrm{F} .\left(37.3^{\circ} \mathrm{C}\right.$.), dyspnoea, wheezing respirations, basal crepitations, and clinical and radiological evidence of right-sided emphysema with mediastinal displacement to the left (Fig. 1). Bronchoscopy excluded the presence of a foreign body and showed a slight narrowing of the right upper lobe bronchial orifice. There was no filling of the upper lobe on a right-sided bronchogram. The pyrexia soon settled but the emphysema persisted. A blood transfusion was required to correct an anaemia with a haemoglobin level of $49 \%(7.3 \mathrm{~g} . / 100 \mathrm{ml}$.). When the child was aged 9 months, the emphysematous right upper lobe was resected by Mr. Vernon Thompson. The bronchus was divided without the application of clamps, so that the pathology would not be distorted. Since the operation a year ago the boy has been symptom free.

Pathology of the Resected Lobe.-Macroscopic examination of the formalin-fixed uninflated right upper lobe showed generalized post-resection collapse. The main bronchus and its segmental divisions, although possibly a little narrow, were otherwise normal.

In none of the sections examined macroscopically was the bronchial cartilage absent or apparently hypoplastic, nor were there any mucosal folds. The mucosa of the main bronchus was a little oedematous and lightly infiltrated with round cells, and its lumen contained a little mucus and some desquamated epithelial cells (Fig. 2).

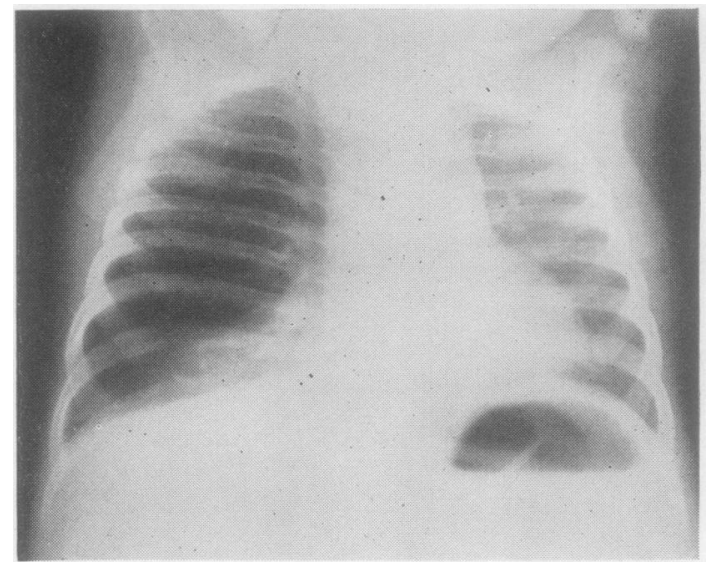

FIG. 1.-Radiograph of the chest of an infant with congenital lobar emphysema taken the day before right upper lobectomy. 


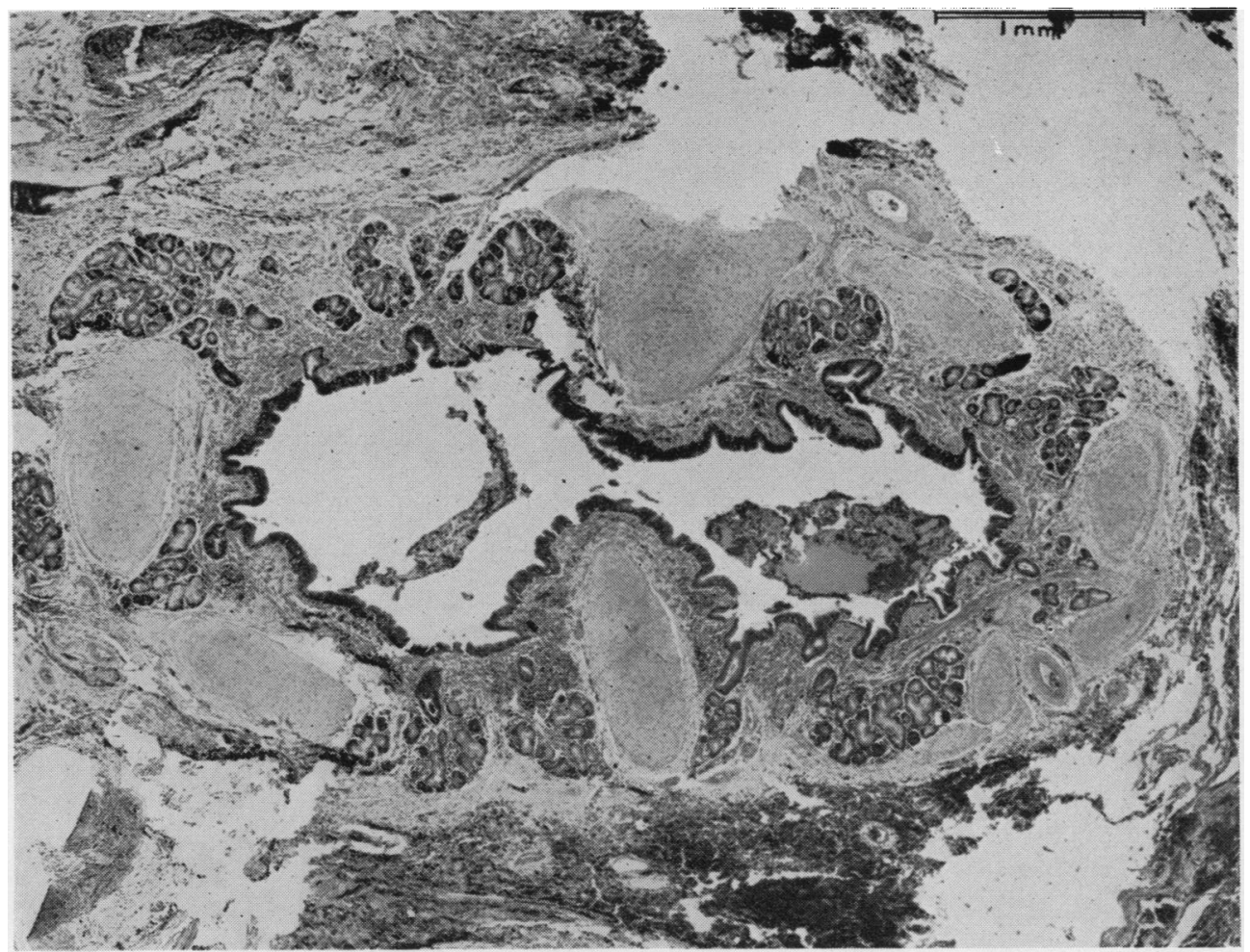

Fig. 2. Section from the cut end of the right upper lobe bronchus. Haematoxylin and eosin, $\times 21.5$.

In view of these negative findings and bearing in mind the number of cases reported with hypoplastic bronchial cartilages, the technique of examining whole mounts of lengths of bronchi was developed in order to investigate further the structure of the bronchial wall.

\section{Technique of Bronchial Whole Mounts}

Short lengths of the main segmental bronchi were dissected out, freed of adventitia, incised along their length, and opened out flat. A preliminary wash in tap water was found to improve their subsequent staining. The preparations were stained for 24 to 72 hours in dilute toluidine blue at $p \mathrm{H} 1$, dehydrated, and cleared in successive changes in acetone, cedar wood oil, and xylol and finally mounted in thick Canada balsam. The cartilages appear purple or deep blue-black against a green-blue background.

ObSERvations.-Several control specimens from neonatal and infantile deaths up to 1 year of age showed stout bars of cartilage with varying degrees of spacing between them (Figs. 3 and 4). The cartilages tend to run transversely, but there are also longitudinally directed processes. In the present case the lobectomy specimen was re-examined after the selection of material for routine microscopical examination and the short remaining lengths of the main segmental bronchi were dissected and stained as above. These portions of bronchi were immediately peripheral to the hilar section shown in Fig. 2. It is seen (Fig. 5a and $b$ ) that the bronchial cartilages have a thin spidery form tending to run predominantly in a longitudinal direction. This is more evident in one of the bronchi than in the other, but both show this abnormal morphology. The bronchial cartilages in a 20-weeks gestation are similar to the other controls (Fig. 6), which suggests that the spidery shapes seen in the present cases are true aberrations and not the persistence of a foetal form.

No comparable study appears to have been made since that of King (1840, cited by Miller, 1947), who made dissection preparations of the cartilages of the main bronchi of adults.

\section{Discussion}

Probably the earliest recorded case of congenital lobar emphysema is that of Bartholinus (1687, cited by Koontz, 1925). Meyer in 1859 (quoted by Miller, 1926) described the pathology of a complex case in which several lesions were present; a large residual ductus arteriosus, small bronchi with folded mucosa, and bullous emphysema. The bronchial cartilages 


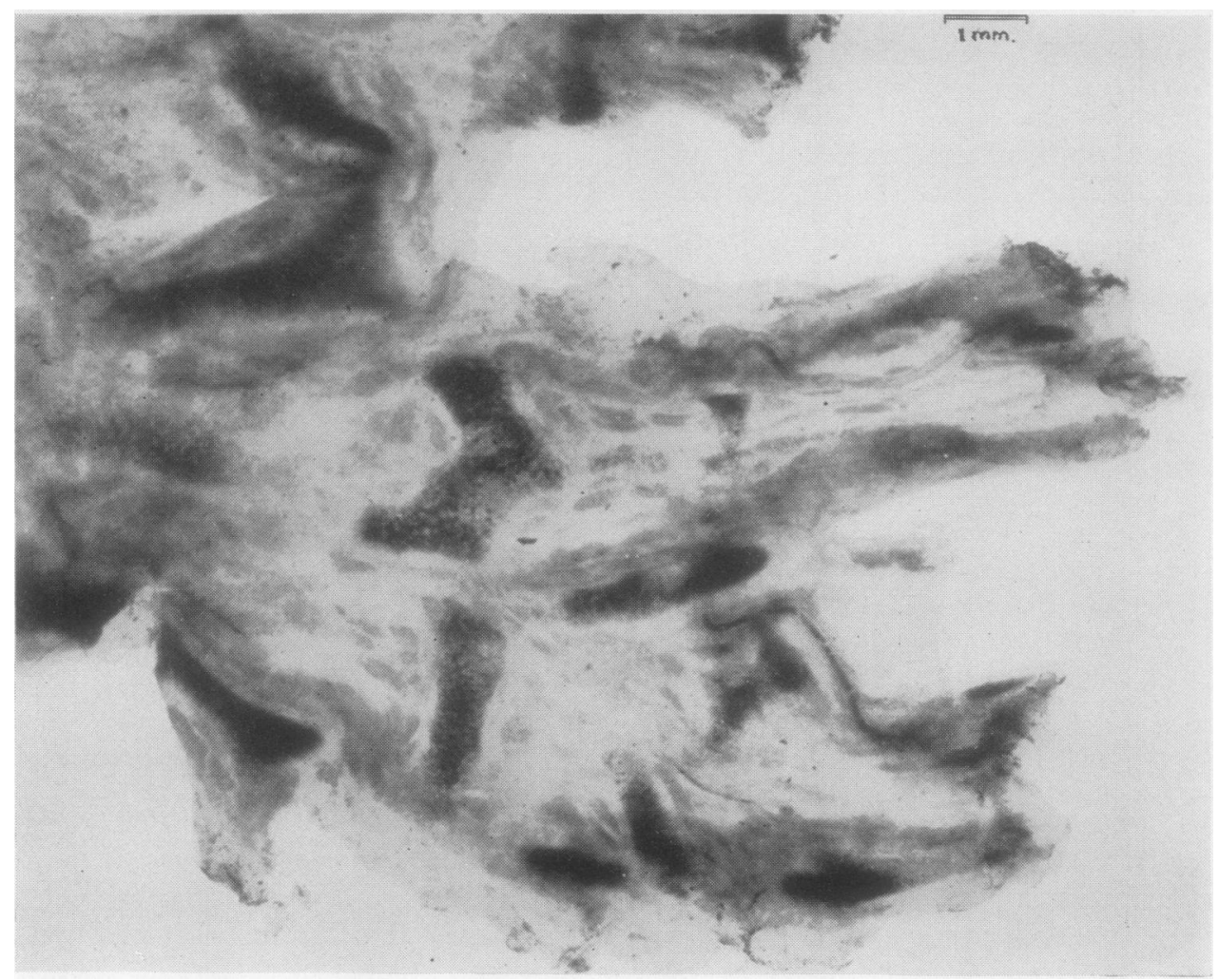

FIG. 3.-Whole mount of apical segmental bronchus of right upper lobe of a 1-year-old hydrocephalic female, $\times 9$.

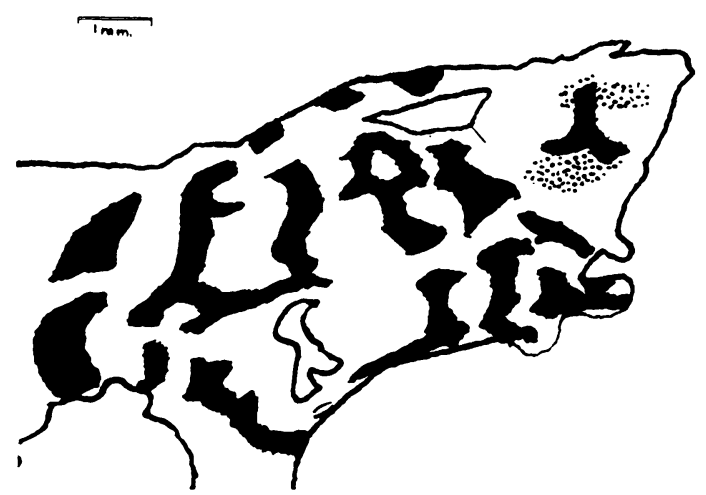

FIG. 4.-Camera lucida tracing of whole mount of anterior segmental bronchus of right upper lobe of a 10-month-old hydrocephalic female, $\times 8.4$. were not commented on, though the folded state of the bronchial mucosa might suggest that there was some collapse of the bronchi from poorl@ developed cartilages. Overstreet (1939) was the्x first to draw attention to a deficiency of bronchiat cartilage as the sole cause of lobar emphysema.

In those published cases in which the bronchiab cartilages have been either absent or hypoplastie the pathology has been determined by bronchoo scopy (Ferguson and Neuhauser, 1944), or by macroscopic examination of the specimen (Gros and Lewis, 1945), or by the appearances iñ conventional microscopic sections (Nelson, 1932 Overstreet, 1939 ; Cassinelli, 1944 ; Fischer, Potts and Holinger, 1952; Shaw, 1952; Bolande N Schneider, and Boggs, 1956; Holzel and otherso 1956 ; Cottom and Myers, 1957 ; Nelson, 1957) In some of the latter reports small nodules of cartilage, possibly corresponding to the section of a spidery bar, have been illustrated (Cassinelli.g 1944 ; Cottom and Myers, 1957), and Nelsorō (1957) described the cartilages seen in the routin sections of his seventh case as small immature bars of cartilage, but in no instance has ant 


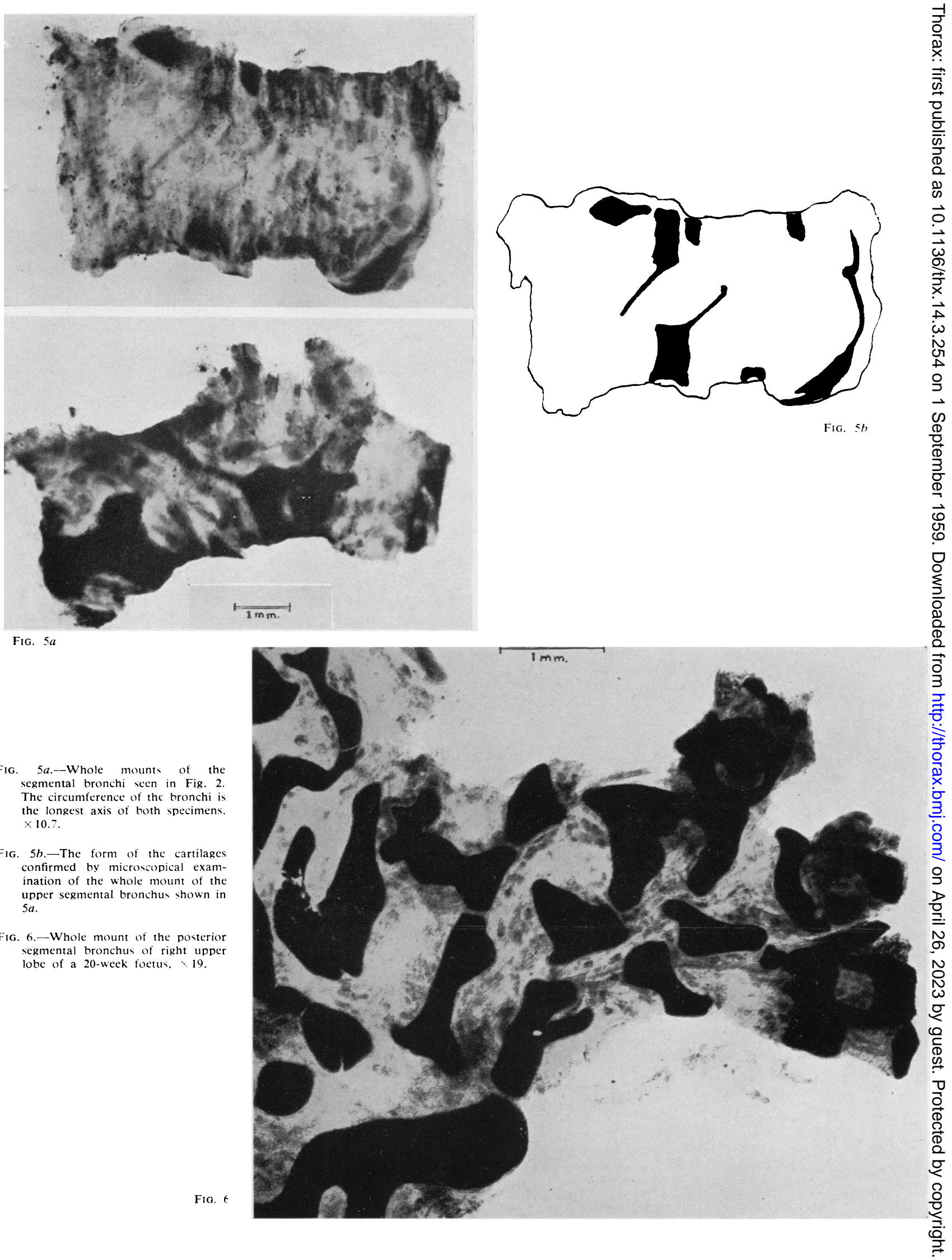


reconstruction of the shape or direction of the cartilage been attempted.

The present case illustrates the possible extremely focal nature of the defect in the cartilages in that routine sections at either end of the whole mount appeared normal. Nelson's fourth case (1957) also showed a localized absence of cartilage, found only at post-mortem examination of the lobectomy stump, a deficiency of cartilage having been noticed in the bronchus of the resected left upper lobe. Poor development of cartilages extensively throughout the bronchi of the emphysematous lobe have been recorded by Cassinelli (1944), Cottom and Myers (1957), and Nelson (1957). In most instances the main bronchus or its inferior division has normal cartilages, but in the seventh case of Bolande and others (1956) and apparently in the cases of Ferguson and Neuhauser (1944) the main bronchi were affected. In no case have the cartilage cells been described as abnormal, and the present case is no exception.

The clinical details of these cases are given in Table I. The first case of Fischer and others (1952) has been included even though mucosal folds were present, as these folds may be due to the collapsed state of the bronchus secondary to the cartilaginous deficiency. The cases of

TABLE I

PUBLISHED CASES OF CONGENITAL LOBAR EMPHYSEMA DUE TO DEFECTIVE DEVELOPMENT OF BRONCHIAL

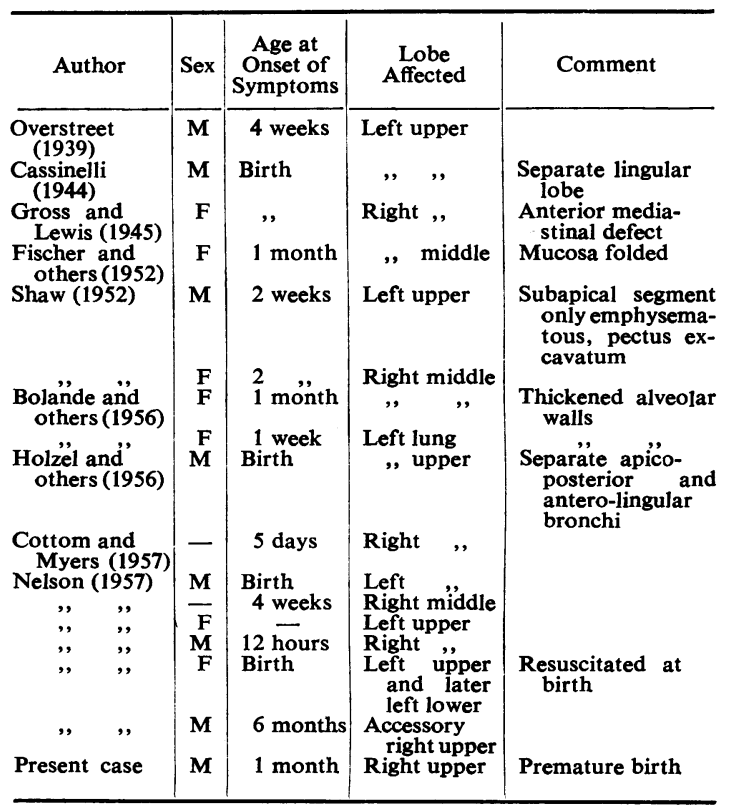

Meyer (1859, quoted by Miller, 1926) and Nelson (1932) have been omitted from the table, as they showed several different abnormalities in addition to the absent cartilages. The three cases of Ferguson and Neuhauser (1944) have not been included because of the lack of clinical details.

The clinical aspects will be further discussed in relation to the two other major groups of congenital lobar emphysema: those due to external bronchial compression, and those in which no causative lesion can be found. For convenience this latter group will be called the idiopathic group.

EXternal Compression Group.-This is a frequently reported cause of congenital lobar emphysema. In practically all cases the compressing agent is an abnormally large or an abnormally situated vessel, but Leahy and Butsch (1949) reported one due to pressure from a gastric cyst. Table II shows the clinical features of this group. The first case of Cottom and Myers (1957) has not been included because there was no conclusive evidence for the existence of a lobar emphysema before the pulmonary valvotomy, and the emphysema may have been due to a bronchial oedema or catarrh induced by the anaesthetic. The third case of these authors is acceptable, as the emphysema was noticed to be present at the time of the division of the patent ductus arteriosus. The emphysema became more severe in the immediate postoperative period. Potts and others (1954) and Contro and others (1958a) were more fortunate in being able to relieve the emphysema by dividing and resuturing an abnormal vessel so that it no longer compressed the thin-walled bronchus.

Although most cases of emphysema due to vascular external compression of the bronchi have been lobar, some cases with emphysema of a whole lung have been included in this group as the mechanism producing the emphysema appears to be the same.

It is useful at this point to consider the reasons why the upper lobes are so predominantly affected. In those cases due to compression by abnormal vessels the anomalies involve the superior part of the mediastinum and are therefore more likely to involve the upper lobes. Why the group with abnormal cartilages should have a similar distribution is less easy to understand, but the developmental aberration responsible for this change may be related to the factor producing unusual branching of the bronchi, which was seen in two cases in this group (Cassinelli, 1944 ; Holzel and others, 1956), and 
TABLE II

PUBLISHED CASES OF CONGENITAL LOBAR EMPHYSEMA DUE TO EXTERNAL COMPRESSION OF THE BRONCHUS

\begin{tabular}{|c|c|c|c|c|}
\hline \multirow{2}{*}{$\begin{array}{c}\text { Author } \\
\text { ernan (1944) }\end{array}$} & \multirow{2}{*}{$\frac{\text { Sex }}{M}$} & \multirow{2}{*}{$\begin{array}{c}\begin{array}{c}\text { Age at } \\
\text { Onset of } \\
\text { Symptoms }\end{array} \\
\text { Birth }\end{array}$} & $\begin{array}{l}\text { Lobes } \\
\text { Affected }\end{array}$ & Comment \\
\hline & & & Right lung & $\begin{array}{l}\text { Anomalous veins, } \\
\text { left lung col- } \\
\text { lapsed, 11 lb. } \\
\text { birth weight }\end{array}$ \\
\hline $\begin{array}{l}\text { Leahy and } \\
\text { Butsch (1949) }\end{array}$ & $\mathbf{M}$ & Birth & , middle & Gastric cyst \\
\hline $\begin{array}{l}\text { Robertson and } \\
\text { James (1951) }\end{array}$ & $\mathbf{M}$ & 20 weeks & ,, upper & Anomalous veins \\
\hline $\begin{array}{l}\text { Fischer and } \\
\text { others (1952) }\end{array}$ & - & 3 , , & Left & $\begin{array}{l}\text { Ductus arteriosus, } \\
\text { lingula collapsed }\end{array}$ \\
\hline ,", , & $\mathbf{M}$ & $6 \frac{1}{2}$ months & , & $\begin{array}{l}\text { Ductus arteriosus, } \\
\text { abnormal bron- } \\
\text { chial division }\end{array}$ \\
\hline $\begin{array}{l}\text { Potts and } \\
\text { others (1954) }\end{array}$ & $\mathbf{M}$ & Birth & Right lung & $\begin{array}{c}\text { Anomalous pul- } \\
\text { monary artery, } \\
\text { artery } \\
\text { planted }\end{array}$ \\
\hline $\begin{array}{l}\text { Morse and } \\
\text { Gladding } \\
\text { (1955) }\end{array}$ & $\mathbf{M}$ & , & ", & $\begin{array}{l}\text { Anomalous pul- } \\
\text { monary artery, } \\
\text { temporary relief } \\
\text { after transplant- } \\
\text { ing artery }\end{array}$ \\
\hline $\begin{array}{l}\text { Bolande and } \\
\text { others (1956) }\end{array}$ & $\mathbf{M}$ & 3 weeks & Left upper & $\begin{array}{l}\text { Ductus arteriosus, } \\
\text { thickened alveo- } \\
\text { lar walls }\end{array}$ \\
\hline $\begin{array}{l}\text { Cottom and } \\
\text { Myers (1957) }\end{array}$ & $\mathbf{F}$ & Birth & , , , & Ductus arteriosus \\
\hline , , , & - & , & , , , & $\begin{array}{l}\text { Ductus arteriosus, } \\
\text { difficult resuscita- } \\
\text { tion at birth, } \\
\text { cleft palate and } \\
\text { accessory thumb }\end{array}$ \\
\hline , & - & 5 weeks & Right middle & $\begin{array}{cc}\text { Aneurysmal } & \text { pul- } \\
\text { monary } & \text { artery, } \\
\text { V.S.D., } & \text { sacral } \\
\text { anomaly } & \end{array}$ \\
\hline Belsey (1958) & $\mathbf{M}$ & 10 days & Left upper & $\begin{array}{l}\text { Abnormal pulmon- } \\
\text { ary artery, birth } \\
\text { asphyxia }\end{array}$ \\
\hline $\begin{array}{l}\text { Contro and } \\
\text { others } \\
\qquad(1958 a)\end{array}$ & $\mathbf{M}$ & 9 :, & Right lung & $\begin{array}{c}\text { Anomalous } \\
\text { monary } \\
\text { artery } \\
\text { artery, } \\
\text { trans- }\end{array}$ \\
\hline , $\quad(1958 b)$ & $\mathbf{M}$ & Birth & Left & $\begin{array}{l}\text { planted } \\
\text { Aneurysmal pul- } \\
\text { monary artery, } \\
\text { Fallot's tetralogy, } \\
\text { imperforate anus }\end{array}$ \\
\hline , & $\mathbf{F}$ & 13 days & , , , & $\begin{array}{l}\text { Aneurysmal pul- } \\
\text { monary artery, } \\
\text { Fallot's tetralogy }\end{array}$ \\
\hline $\begin{array}{c}\text { Sherman } \\
\text { (1959) }\end{array}$ & $\mathbf{M}$ & Birth & $\begin{array}{l}\text { Right middle } \\
\text { and lower }\end{array}$ & $\begin{array}{l}\text { Anomalies of pul- } \\
\text { monary artery } \\
\text { and aorta, } 5 \text { lb. } \\
11 \text { oz. birth } \\
\text { weight }\end{array}$ \\
\hline
\end{tabular}

an accessory right upper lobe was present in one other case (Nelson, 1957). These branching aberrations are usually confined to one lobe and this is usually an upper lobe.

It seems therefore that the explanation invoked by Fischer and others (1952) to explain the upper lobar distribution is not correct in some groups, although it may hold for the idiopathic group. These authors attributed the predominant upper lobe involvement to the greater ability of the lower ribs, intercostal muscle, and diaphragm to force air out of the lower lobes during expiration. This may explain the spontaneous recovery of the only case of purely lower lobe emphysema which I have been able to find in the literature (Caffey, 1953), but this reasoning is inadequate in explaining the uniform emphysema of a whole lung seen in a few cases in the external compression group, and in the seventh case of Bolande and others (1956) due to absence of cartilages in the left main bronchus.

Idiopathic Group.-Although Lewis and Potts (1951) attributed the emphysema in their case to herniation of the middle lobe through an anterior mediastinal defect, I have included it in this group because there was no further development of emphysema after the middle lobectomy even though the mediastinal defect was left unrepaired. An anterior mediastinal defect was also present in the second case of Bolande and others (1956), but this case has been excluded from the idiopathic group because of the presence of hyaline membranes. The first and third cases of these authors have also been excluded because they are respectively cystic lung disease and due to bronchitis. Because of cystic changes Ehrenhaft and Taber's first two cases (1953) have been excluded and their third case was shown later (Van Epps and Davies, 1955) to have a

TABLE III

PUBLISHED CASES OF "IDIOPATHIC" CONGENITAL LOBAR EMPHYSEMA

\begin{tabular}{|c|c|c|c|c|}
\hline Author & Sex & $\begin{array}{c}\text { Age at } \\
\text { Onset of } \\
\text { Symptoms }\end{array}$ & $\begin{array}{c}\text { Lobe } \\
\text { Affected }\end{array}$ & Comment \\
\hline $\begin{array}{l}\text { Lewis and Potts } \\
\text { (1951) }\end{array}$ & $\mathbf{M}$ & 6 weeks & Right middle & $\begin{array}{l}\text { Anterior medias- } \\
\text { tinal defect }\end{array}$ \\
\hline $\begin{array}{c}\text { Robertson and } \\
\text { James (1951) }\end{array}$ & $\begin{array}{r}\text { M } \\
\text { F }\end{array}$ & $\begin{array}{ll}2 & \Rightarrow \\
5 & \text { months }\end{array}$ & , $\quad$ upper & \\
\hline $\begin{array}{l}\text { Fischer and } \\
\text { others (1952) }\end{array}$ & $\mathbf{M}$ & $\begin{array}{l}5 \text { months } \\
2 \text { weeks }\end{array}$ & ", $\quad$ middle & $\begin{array}{l}\text { Difficult delivery, } \\
\text { one-third of lobe } \\
\text { collapsed }\end{array}$ \\
\hline ", " & $\mathbf{M}$ & $6 \quad "$ & Left $\quad "$ & $\begin{array}{l}\text { Inflamed bronchus } \\
\text { in collapsed lin- } \\
\text { gula }\end{array}$ \\
\hline $\begin{array}{c}\text { Ehrenhaft and } \\
\text { Taber (1953) }\end{array}$ & F & 1 week & Right middle & \\
\hline Sloan (1953) & $\mathbf{F}$ & 7 weeks & Left upper & \\
\hline$" \quad "$ & $\mathbf{M}$ & 6 days & $\begin{array}{l}\text { Left lung and } \\
\text { right middle }\end{array}$ & $\begin{array}{l}\text { Middle lobe } \\
\text { resected }\end{array}$ \\
\hline $\begin{array}{l}\text { White-Jones } \\
\text { and Temple } \\
\text { (1954) }\end{array}$ & $\mathbf{M}$ & 2, & Left upper & $\begin{array}{l}\text { Diaphragmatic her- } \\
\text { nia noticed } 3 \\
\text { months after } \\
\text { lobectomy }\end{array}$ \\
\hline $\begin{array}{l}\text { Bolande and } \\
\text { others (1956) }\end{array}$ & $\mathbf{M}$ & Birth & Right , & $\begin{array}{l}\text { Thickened alveolar } \\
\text { walls }\end{array}$ \\
\hline $\begin{array}{l}\text { Silver and } \\
\text { others (1956) }\end{array}$ & M & Few days & Left , & $\begin{array}{l}\text { Difficult delivery, } \\
\text { collapsed lingula }\end{array}$ \\
\hline $\begin{array}{l}\text { Cottom and } \\
\text { Myers (1957) } \\
\text { Nelson (1957) }\end{array}$ & $\bar{M}$ & $\begin{array}{l}6 \text { weeks } \\
\text { Birth }\end{array}$ & " & \\
\hline ", & & 10 days & Right middle & $\begin{array}{l}\text { Bronchi thin-walled } \\
\text { with normal his- } \\
\text { tology }\end{array}$ \\
\hline $\begin{array}{l}\text { Egan and } \\
\text { others (1958) }\end{array}$ & $\mathbf{M}$ & 1 month & Left upper & Difficult delivery \\
\hline $\begin{array}{l}\text { Jewett and } \\
\text { Adler (1958) }\end{array}$ & $\mathbf{M}$ & 1 day & Right , " & $\begin{array}{l}\text { One month prema- } \\
\text { ture, resuscitated }\end{array}$ \\
\hline ", ", & $\mathbf{F}$ & $\begin{array}{l}4 \text { weeks } \\
\text { Birth }\end{array}$ & ", middle & $\begin{array}{l}\text { Caesarean delivery, } \\
\text { resuscitated, duc- } \\
\text { tus arteriosus } \\
\text { ligated at } 6 \text { mths }\end{array}$ \\
\hline
\end{tabular}


complicating lipoid pneumonia. The onset of Sloan's second case (1953) appears to have been due to the probable inhalation of milk and has therefore not been included in Table III, which gives the clinical details of the idiopathic group.

OTHER Minor Groups.-These are listed in Table IV. Robertson and James (1951) are not

TABLE IV

PUBLISHED CASES OF CONGENITAL LOBAR EMPHYSEMA ATTRIBUTED TO VARIOUS RARER CAUSES

\begin{tabular}{|c|c|c|c|c|c|}
\hline Group & Author & Sex & $\begin{array}{c}\text { Age at } \\
\text { Onset } \\
\text { of Symp- } \\
\text { toms }\end{array}$ & $\begin{array}{c}\text { Lobe } \\
\text { Affected }\end{array}$ & Comment \\
\hline $\begin{array}{l}\text { Mucosal } \\
\text { fold }\end{array}$ & $\begin{array}{c}\text { Robertson } \\
\text { and James } \\
\text { (1951) } \\
\text {," }\end{array}$ & $\begin{array}{l}\mathbf{M} \\
\mathbf{M}\end{array}$ & $\begin{array}{l}2 \text { weeks } \\
3,\end{array}$ & $\begin{array}{l}\text { Right } \\
\text { upper } \\
\text { Left upper }\end{array}$ & $\begin{array}{l}\text { A little peribron- } \\
\text { chial collapse }\end{array}$ \\
\hline $\begin{array}{l}\text { Bronchial } \\
\text { atresia }\end{array}$ & $\begin{array}{c}\begin{array}{c}\text { Belsey } \\
\text { (1958) }\end{array} \\
,,\end{array}$ & $\begin{array}{l}\mathbf{M} \\
\mathbf{M}\end{array}$ & $\begin{array}{l}\text { Birth } \\
5 \frac{1}{2} \text { years }\end{array}$ & $\begin{array}{l}\text { Right } \\
\text { upper } \\
\text { Left upper }\end{array}$ & $\begin{array}{l}\text { Pin hole orifice } \\
\text { to lobar bron- } \\
\text { chus } \\
\text { No orifice to } \\
\text { lobar bron- } \\
\text { chus, hyper- } \\
\text { plastic bron- } \\
\text { chial cart- } \\
\text { lages, abnor- } \\
\text { mal pulmonary } \\
\text { arteries to the } \\
\text { lobe }\end{array}$ \\
\hline $\begin{array}{l}\text { Asthma- } \\
\text { like } \\
\text { group }\end{array}$ & $\begin{array}{l}\text { Williams } \\
\text { (1952) } \\
\text { Sloan } \\
\text { (1953) } \\
\text { Holzel } \\
\text { and } \\
\text { others } \\
\text { (1956) }\end{array}$ & $\begin{array}{l}\text { M } \\
\text { M } \\
\text { F }\end{array}$ & $\begin{array}{l}\text { Birth } \\
3 \text { weeks } \\
4 \text {," }\end{array}$ & $\begin{array}{l}\text { Right } \\
\text { middle } \\
\text { Right } \\
\text { middle } \\
\text { Left upper } \\
\text { and later } \\
\text { left lower }\end{array}$ & $\begin{array}{l}\text { Mild diffuse in- } \\
\text { flammation in } \\
\text { lobe }\end{array}$ \\
\hline
\end{tabular}

the only authors to describe mucosal folds. One case (Fischer and others, 1952) has been discussed in the deficient cartilage group above. Mucosal folds were noticed by Leahy and Butsch (1949), but the patches of collapse noticed histologically in the emphysematous lobe must raise the suspicion that the emphysema was due to inflammation. It is interesting that these authors considered the mucosal folds to be in the nature of a mucosal prolapse secondary to the emphysema.

The five cases which Weisel (1955) claimed to have improved by bronchial dilatation might belong to the atretic group, but no histological studies were described. Belsey (1958), besides giving details of two atretic cases, mentions bronchial tumours as a further possible cause of lobar emphysema, some of which might be congenital.

There is a small group of cases with evidence of bronchial neuromuscular dysfunction similar to asthma but of a more localized nature. Williams's case (1952) and Sloan's first case (1953) both obtained temporary symptomatic relief from adrenaline, and the former case showed bulbous thickening of the interalveolar septa which may have been hypertrophic muscle bundles in the respiratory bronchioles. The second case of Holzel and others (1956) also probably belongs to this group and adrenaline was beneficial for the relapse after lobectomy.

Hyaline membranes were present in the second case of Bolande and others (1956) and thickened alveolar walls were mentioned in all their cases, but the clinical details are not suggestive of hyaline membrane disease. The history of Ehrenhaft and Taber's seventh case (1953) is suggestive of this disease, but no hyaline membranes were observed. Ehrenhaft and Taber postulated that traumatic interstitial emphysema might cause infantile lobar emphysema, but there is no histological and only slight clinical evidence in favour of this hypothesis. These two possible aetiological factors therefore do not appear in Table IV.

The salient points in the clinical data of the three main groups are summarized in Table $\mathrm{V}$.

TABLE V

SUMMARY OF SOME FEATURES OF THE THREE PRINCIPAL GROUPS OF CONGENITAL LOBAR EMPHYSEMA

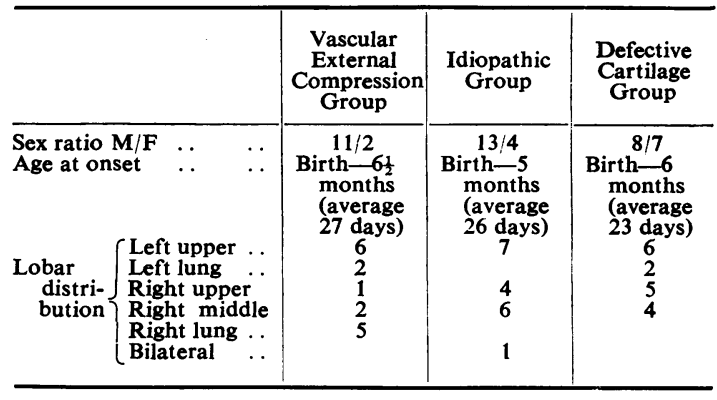

Though the groups are small there appears to be one feature distinguishing the defective-cartilage group from the other two, namely a higher proportion of females. In addition, although the average age for the onset of symptoms in the three main groups is the same, it is much less frequent for the symptoms to begin after the first month in the defective cartilage group (one out of 16) than it is in the other groups (one out of four). These differences may be genuine, but the groups are so small that a definite conclusion must await the description of many more cases in all groups. Certainly the differences between the groups are not sufficient to exclude the possibility of a limited defect in bronchial cartilage, such as 
I have described, having been overlooked in some cases in the idiopathic group. Had not the technique of bronchial whole mounts been evolved the present case would have been included in the idiopathic group.

Whatever the aetiological factors the lobe is described as emphysematous and one must assume that this has meant a simple overdistension without structural damage, as has been shown by Leopold and Gough (1957), and in the illustrations to Sloan's first and third cases, the case of Silver, Kirklin, Harris, and McDonald (1956), and by Nelson (1957). In a few instances damage to alveolar walls has been reported (Overstreet, 1939 ; Robertson and James, 1951 ; Fischer and others, 1952; Shaw, 1952; Williams, 1952 ; Ehrenhaft and Taber, 1953 ; White-Jones and Temple, 1954; Bolande and others, 1956 ; Jewett and Adler, 1958), but this feature has not been prominent in the cases illustrated except for that of White-Jones and Temple (1954) and Case 4 of Ehrenhaft and Taber (1953). It seems possible that Meyer's (1859) case (quoted by Miller, 1926), like Case 5 of Weisel (1955), was one of emphysema with formation of bullae. Silver (1939) reported one infant with lobar emphysema in whom subsequent rupture produced a fatal pneumothorax. Unfortunately no study of the emphysema in my case was possible because it had been decided pre-operatively that the hilum of the specimen would not be touched until after fixation, by which time the lobe had collapsed. Without further details it is impossible to evaluate the variable amount of fibrosis of the alveolar walls observed by Bolande and others (1956). This change appears to be different from the bulbous thickening of alveolar septa described by Williams (1952).

Prognosis.-Two cases (Gross and Lewis, 1945; Shaw, 1952) were each observed for four years without any improvement before lobectomy, and Nelson's ninth case (1957) was operated on six and a half years after the onset of symptoms. Post-operative follow-up studies are rarely reported, the longest being three and a quarter years (Egan, Jewett, and Macmanus, 1958) and two years (White-Jones and Temple, 1954). In the latter case the patient remained well despite the presence of an intrathoracic hernia containing ileum and colon. Symptom-free periods of over one year post-operatively have been recorded by Gross and Lewis (1945), Williams (1952), and Van Epps and Davies (1955). However, not all cases are cured by lobectomy; Sherman's case (1959) and all four of Sloan's cases (1953) had residual respiratory symptoms, but in one of these it was known preoperatively that the other lung was involved. In the asthmatic case of Holzel and others (1956) already mentioned, emphysema of the lower lobe developed after resection of the upper lobe. Similar progression of the emphysema to other lobes has been observed by Nelson (1957) and by Ehrenhaft and Taber (1953). This latter case has not been included in this review because of the possibility that it was one of cystic lung. A few cases have been reported with spontaneous recovery (Caffey, 1953; Holzel and others, 1956). The pathology in these can only be surmised, one possibility being that initially underdeveloped cartilages have grown sufficiently rigid to provide adequate support to the bronchial wall.

The apparent cure obtained by Korngold and Baker (1954) by needle decompression of the emphysematous lobe in two cases emphasizes the distorting and compressing effect that an established lobar emphysema may have on the bronchial tree. Changes of this nature have been observed by Leahy and Butsch (1949), Bolande and others (1956), and Silver and others (1956). The initial cause of the emphysema in the cases of Korngold and Baker was not established, but the limited period of follow-up does not exclude a natural remission such as is seen in some cases of lobar emphysema due to any one of the mechanisms that have been discussed.

\section{SUMMARY AND CONCLUSION}

A case of congenital lobar emphysema is reported and a technique for examining whole bronchi for abnormalities of the bronchial cartilages is described. Using this technique the case was seen to belong to the group of cases with hypoplastic cartilages and not to the idiopathic group of cases.

A survey of cases in the literature has been analysed. It is suggested that the idiopathic group includes a few cases in which defective bronchial cartilages have been missed.

I wish to thank Dr. K. H. Tallerman and Mr. Vernon C. Thompson for permission to publish details of their case, Professor D. S. Russell for her interest and advice, Dr. C. W. M. Adams and Mr. V. Trenwith for help with the staining technique, and Mrs. M. Smitten for secretarial assistance.

\section{REFERENCES}

Belsey, R. H. R. (1958). Brit. J. Tuberc., 52, 53.

Bolande, R. B., Schneider, A. F., and Boggs, J. D. (1956). A.M.A. Arch. Path., 61, 289.

Caffey, J. (1953). Pediatrics, 11, 48.

Cassinelli, J. F. (1944). Hoja tisiol., 4, 230 and 365. 
Contro, S., Miller, R. A., White, H., and Potts, W. J. (1958a). Circulation, 17, 418.

- (1958b). Ibid., 17, 424.

Cottom, D. G., and Myers, N. A. (1957). Brit. med. J., 1, 1394.

Egan, R. W., Jewett, T. C., and Macmanus, J. E. (1958). A.M.A. Arch. Surg., 77, 584.

Ehrenhaft, J. L., and Taber, R. E. (1953). Surgery, 34, 412.

Ferguson, C. F., and Neuhauser, E. B. D. (1944). Amer. J. Roentgenol., 52, 459.

Fischer, H. W., Potts, W. J., and Holinger, P. H. (1952). J. Pediat., 41, 403 .

Gross, R. E., and Lewis, J. E. (1945). Surg. Gynec. Obstet., 80, 549.

Holzel, A., Bennett, E., and Vaughan, B. F. (1956). Arch. Dis. Childh., 31, 216.

Jewett, T. C., and Adler, R. H. (1958). Surgery, 43, 926.

Kernan, J. D. (1944). Ann. Otol. (St. Louis), 53, 818.

Koontz, A. R. (1925). Bull. Johns Hopk. Hosp., 37, 340.

Korngold, H. W., and Baker, J. M. (1954). Pediatrics, 14, 296.

Leahy, L. J., and Butsch, W. L. (1949). Arch. Surg. (Chicago), 59, 466.

Leopold, J. G., and Gough, J. (1957). Thorax, 12, 219.

Lewis, J. E., and Potts, W. J. (1951). J. thorac. Surg., 21, 438.
Miller, R. T. (1926). Arch. Surg. (Chicago), 12, 392.

Miller, W. S. (1947). The Lung, 2nd ed., p. 26. Charles C. Thomas Springfield, Illinois.

Morse, H. R., and Gladding, S. (1955). Amer. J. Dis. Child., 89, 351

Nelson, R. L. (1932). J. Pediat., 1, 233.

Nelson, T. Y. (1957). Arch. Dis. Childh., 32, 38.

Overstreet, R. M. (1939). Amer. J. Dis. Child., 57, 861. Potts, W. J., Holinger, P. H., and Rosenblum, A. H. (1954). J.
Amer. med. Ass., 155, 1409 .

Robertson, R., and James, E. S. (1951). Pediatrics, 8, 795.

Shaw, R. R. (1952). Ibid., 9, 220.

Sherman, F. E. (1959). J. Pediat., 54, 93.

Silver, A. W., Kirklin, J. W., Harris, L. E., and McDonald, J. R (1956). Dis. Chest, 30, 456.

Silver, H. B. (1939). Amer. J. Dis. Child., 57, 907.

Sloan, H. (1953). J. thorac. Surg., 26, 1.

Van Epps, E. F., and Davies, D. H. (1955). Amer. J. Roentgenol. 73, 375 .

Weisel, W. (1955). Ann. Surg., 142, 17. Weisel, W. (1955). Ann. Surg., 142, 17.
White-Jones, R. H., and Temple, L. J. (1954). Arch. Dis. Childh.
29, 248.

Williams, M. H. (1952). J. thorac. Surg., 2^, 522. 